\title{
RANCANG BANGUN ALAT PEMBERI PAKAN OTOMATIS TERHADAP KUCING PELIHARAAN MENGGUNAKAN ARDUINO UNO
}

\author{
Wafa Tajul Arifin Bisri ${ }^{1}$ \\ Progran Studi Teknik Elektro Universitas Panca Marga Probolinggo \\ Email:wafatajularifin@gmail.com \\ $\underline{\text { Ira Aprilia }}^{1}$ \\ Program Studi Teknik Elektro Universitas Panca Marga \\ Email: ira.aprilia11@upm.ac.id
}

\begin{abstract}
Cats is one of the most popular animals in the world that have various breeds. One of the most popular types is Persian and Angora. It requires discipline and persistence both in maintaining cleanliness and also in providing food in caring cats. Constraints in feeding cats are due to the routine activities of the owner outside the home, so providing cat food every day cannot be controlled properly and can make cats more susceptible to disease. This requires an automatic feeding device that can be used to assist cat owners in providing feed on a scheduled basis. This study uses a microcontroller with Arduino Uno as a control system to control input and output. RTC as a scheduled determinant will give commands to the Arduino Uno to drive the mini servo. Mini servo as the main container activator opens the main container which will later fall into the weighing container. The load cell sensor can weigh the feed which will be poured through the mini servo. The percentage that was tried was up to $99 \%$. It works on the condition that the main container is filled with more feed. However, if the feed is filled with $3 / 4$, the feed that comes out will be more precise.
\end{abstract}

Keywords: Automatic feeder, Arduino Uno, Load cell, Microcontroller, Mini Servo.

\begin{abstract}
ABSTRAK: Kucing merupakan hewan populer di dunia yang mempunyai garis keturunan atau ras yang bermacam-macam salah satunya yang paling banyak digemari adalah jenis persia dan angora. untuk memelihara kucing memerlukan sebuah kedisiplinan dan ketekunan baik dalam merawat kebersihan dan juga dalam pemberian pakan. Kendala dalam pemberian pakan kucing dikarenakan rutinitas kegiatan si pemilik diluar rumah, sehingga pemberian pakan kucing di setiap harinya tidak dapat terkontrol dengan baik dan dapat membuat kucing jadi lebih mudah terserang penyakit. Untuk itu dibutuhkan sebuah mekanisme alat pemberi pakan otomatis yang dapat digunakan untuk membantu pemilik kucing dalam memberikan pakan secara terjadwal. Penelitian ini menggunakan mikrokontroler dengan Arduino uno sebagai sistem control untuk mengendalikan input dan output.RTC sebagai penentu jadwal yang nantinya akan memberi perintah pada Arduino uno untuk menggerakkan mini servo. Mini servo sebagai penggerak wadah utama membuka wadah utama yang nantinya akan jatuh ke wadah timbangan. Sensor loadcell dapat menimbang pakan yang nanti akan dituangkan melalui mini servo. Presentase uii coba yang dilakukan mencapai $99 \%$. Dimana jika wadah utama diisi penuh pakan yang di keluarkan lebih banyak. Namun jika pakan terisi 3/4 maka pakan yang keluar akan lebih presisi.
\end{abstract}

Kata kunci: Alat Pemberi Pakan Otomatis, Arduino Uno, Load cell, Mikrokontroler, Mini Servo.

\section{PENDAHULUAN}

K ucing merupakan hewan populer di dunia yang mempunyai garis keturunan atau ras yang bermacam-macam salah satunya yang paling banyak digemari adalah jenis persia dan angora. Untuk memelihara kucing memerlukan sebuah kedisiplinan dan ketekunan baik dalam merawat kebersihan dan juga dalam pemberian pakan.

Pakan merupakan kebutuhan penting dalam memelihara kucing, kendala dalam pemberian pakan kucing dikarenakan rutinitas kegiatan si pemilik diluar rumah, sehingga pemberian pakan kucing di setiap harinya tidak dapat terkontrol dengan baik dan dapat membuat kucing jadi lebih mudah terserang penyakit. Pemberian pakan kucing manual dilakukan setiap hari dua kali, pagi hari dan sore hari. Untuk itu dibutuhkan sebuah mekanisme alat pemberi pakan otomatis yang dapat digunakan untuk membantu pemilik kucing dalam memberikan pakan secara terjadwal.

Berdasarkan hal tersebut maka penulis melakukan penelitian dalam merancang "Alat Pemberi Pakan Otomatis terhadap Kucing Peliharaan Menggunakan Arduino Uno" alat ini menggunakan real time a'clock, servo, sensor timbangan serta menggunakan Arduino Uno yang merupakan rangkaian minimum sistem mikrokontroler dan berfungsi sebagai pengontrol sistem.

\section{Mikrokontroler}

\section{KAJIAN PUSTAKA}

Mikrokontroler merupakan pengembangan lebih lanjut dari mikroprosesor. Dalam penggunaan 
mikroprosesor membutuhkan RAM dan ROM untuk membuat sesuatu sistem yang sederhana. Akan tetapi dalam sebuah chip mikrokontroler terdapat piranti-piranti yang telah terintegrasi cukup lengkap di dalamnya, bahkan sekarang mikrokontroler ada yang memiliki piranti-piranti.[5]

\section{Arduino Uno}

Arduino Uno merupakan papan mikrokontroler berbasis ATmega328 yang memiliki 14 pin digital input maupun output (dimana 6 pin dapat digunakan sebagai output PWM), 6 input analog, clock speed $16 \mathrm{MHz}$, koneksi USB, jack listrik header ICSP, dan tombol reset. arduino memerlukan daya yang terhubung ke computer dengan kabel USB atau daya eksternal dengan adaptor AD-DC atau baterai. Arduino Uno ditunjukkan dalam Gambar 1

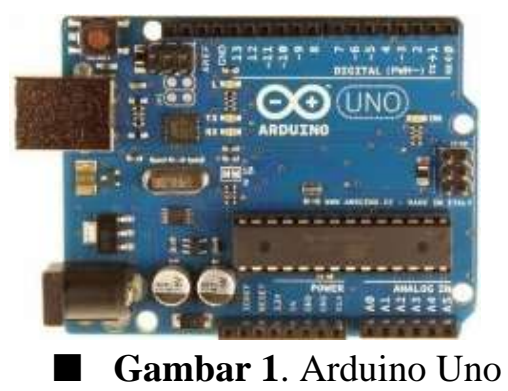

\section{RTC DS3231}

Real Time Clock adalah komponen IC yang dibuat oleh perusahaan Dallas Semiconductor yang memiliki fungsi untuk menghitung ataupun menyimpan waktu baik berupa detik, menit, jam, hari, dan bulan. Modul RTC berupa IC yang dilengkapi dengan komponen seperti crystal sebagai sumber clock dan baterai sebagai sumber energi cadangan agar fungsi dari rtc sendiri dapat berjalan. Komunikasi data dari IC RTC adalah I2C yang merupakan kepanjangan dari Inter Integrated Circuit. Pengaksesan data dilakukan dengan sistem serial yang hanya membutuhkan dua jalur untuk mengirim informasi data clock dan jalur data yang membawa data. Dengan fungsi I2C kita tidak perlu repot lagi dengan mendefinisikan protocol komunikasi I2C, tapi cukup memanggil beberapa fungsi yang telah disediakan oleh CodeVisionAR. Semua mikrokontoler sudah dilengkapi dengan fitur komunikasi 2 jalur ini. Tiny RTC 12c. [10]

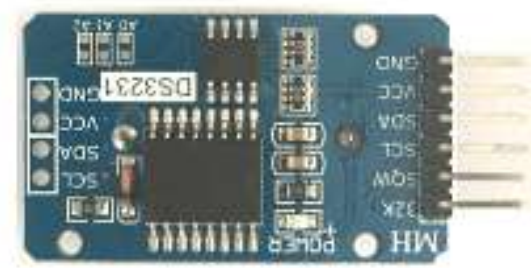

- Gambar 2. RTC

\section{Motor Servo}

Motor Servo adalah jenis motor DC dengan sistem umpan balik tertutup yang terdiri dari sebuah motor DC, serangkaian gear, rangkaian kontrol, dan juga potensiometer. Jadi motor servo sebenarnya tak berdiri sendiri, melainkan didukung oleh komponen-komponen lain yang berada dalam satu paket. Motor servo dapat dimanfaatkan pada pembuatan robot, salah satunya sebagai penggerak kaki robot. Motor servo dipilih sebagai penggerak pada kaki robot karena motor servo memiliki tenaga atau torsi yang besar, sehingga dapat menggerakan kaki robot dengan beban yang cukup berat. Pada umumnya motor servo yang digunakan sebagai pengerak pada robot adalah motor servo $180^{\circ}$. [11] 


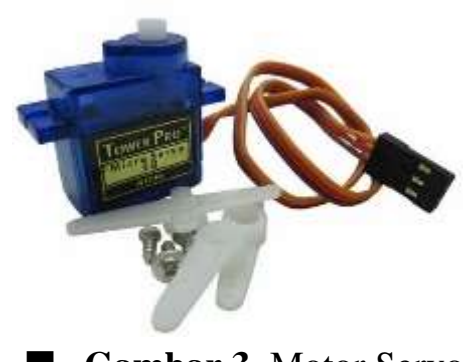

Gambar 3. Motor Servo

\section{Catu Daya}

Catu Daya yang biasa disebut dengan Power Supply ialah sebuah alat yang berguna sebagai sumber daya listrik untuk alat elektronik lain. Pada dasarnya Catu Daya bukan hanya alat yang dapat menghasilkan listrik saja, namun ada juga beberapa Catu Daya yang menghasilkan energi mekanik, dan energi yang lain. Daya untuk menyalakan alat elektronik dapat dari berbagai sumber. Baterai dapat menghasilkan suatu ggl de dengan reaksi kimia. Foton dari panas atau cahaya yang berasal dari matahari dapat diubah menjadi energi listrik dc oleh sel-foto (photocell). Sel bahan bakar menggabungkan gas hidrogen dan oksigen dalam suatu elektrolit untuk menghasilkan ggl dc.

\section{METODE PENELITIAN}

Penelitian ini dilakukan dalam beberapa tahapan. Adapun tahapan-tahapan penelitian ini adalah

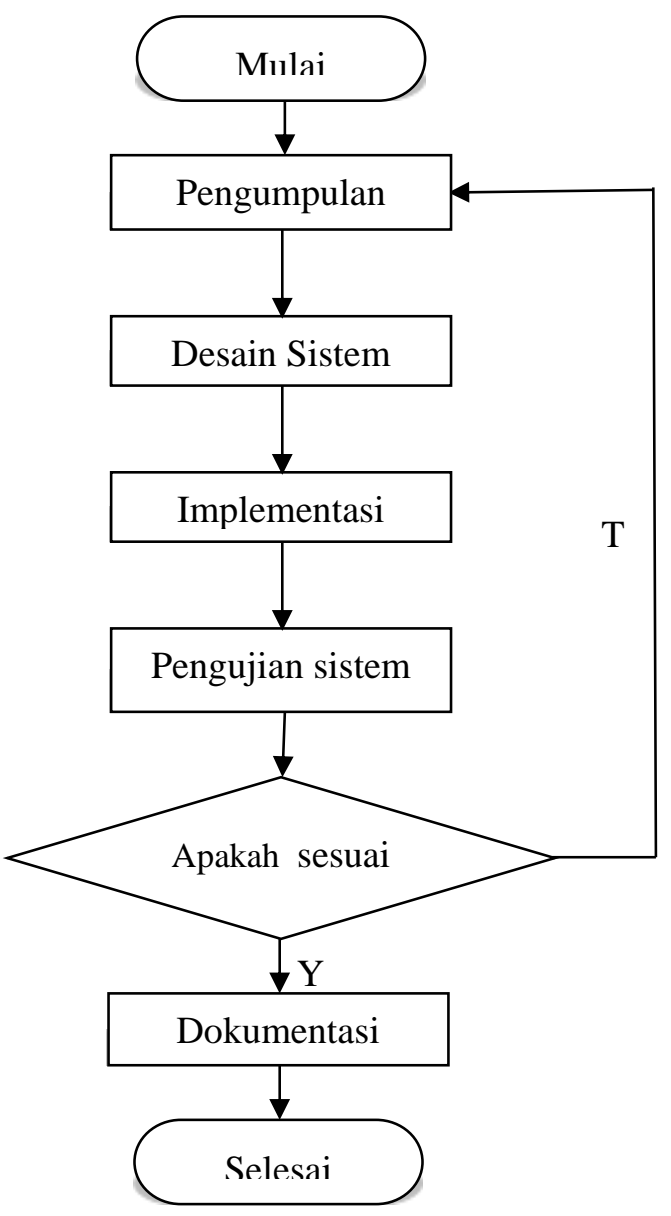

- Gambar 4. Diagram Alir Penelitian

Metode yang dipakai untuk mengumpulkan data dan informasi dari penelitian ini adalah sebagai berikut :

1. Observasi

Melakukan pengamatan dari permasalahan yang ada dikalangan pecinta kucing yang tidak punya banyak waktu untuk memberi pakan. 
2. Studi Pustaka / Studi Literatur

Mengumpulkan maupun mencari data baik melalui jurnal dan situs internet yang berhubungan dengan alat pemberi pakan otomatis. Mancari refrensi-refrensi yang berkaitan dengan masalah yang akan diselesaikan, terutama pada alat yang akan digunakan seperti aplikasi Arduino IDE, Arduino Uno, Modul RTC DS3231, Mini Servo SG90, Load Cell.

\section{Desain Sistem Software dan Hardware}

Desain sistem dilakukan untuk mendapatkan landasan dari pengembangan software dengan mempersiapkan gambaran suatu sistem yang akan dibangun.

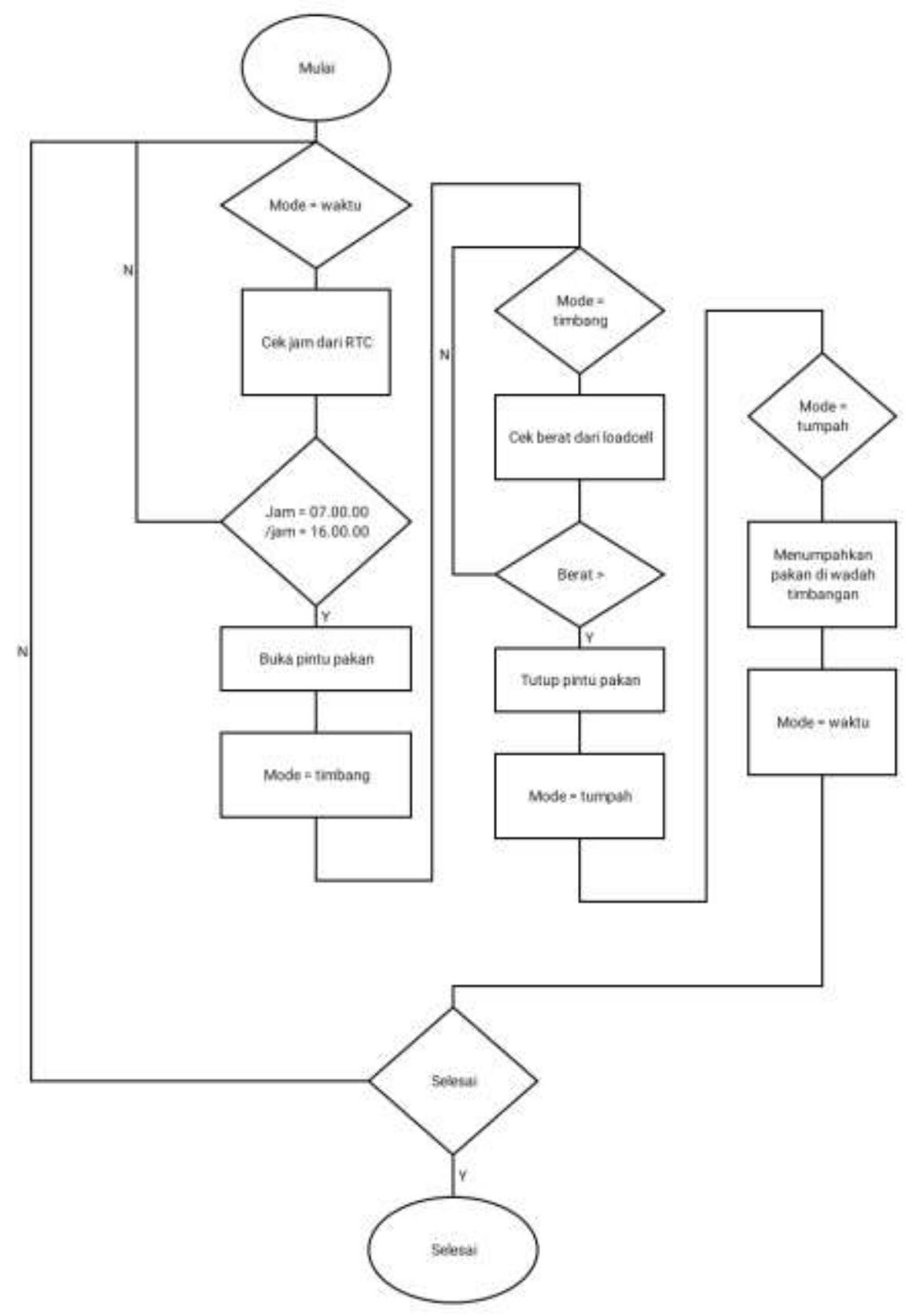

- Gambar 5. Flowchart Sistem

Gambar 5 menjelaskan secara rinci tentang sistem kerja keseluruhan alat pemberi pakan kucing otomatis. 


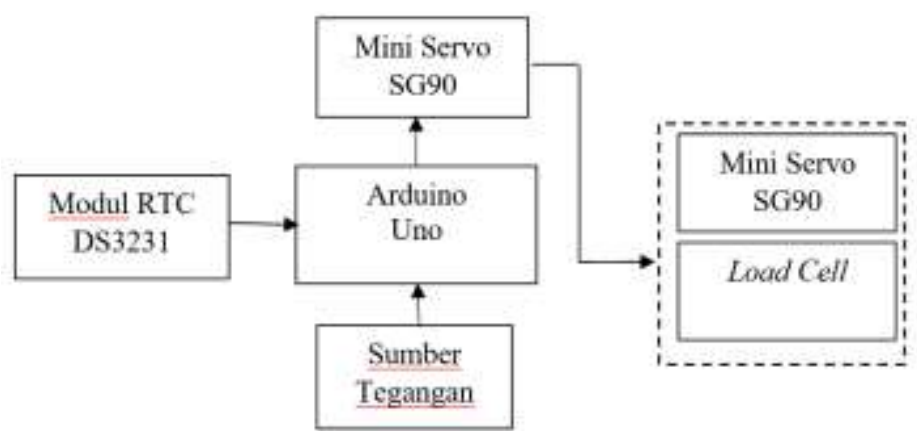

- Gambar 6. Desain Perangkat

Gambar 6 menjelaskan secara rinci desain perangkat-perangkat apa saja yang akan digunakan untuk merancang alat pemberi pakan kucing otomatis.

\section{Analisa Sistem}

\section{HASIL DAN PEMBAHASAN}

Sebelum melakukan tahap perancangan sistem, tahap yang dilakukan sebelumnya adalah menganalisa sistem yang akan dirancang agar dapat berjalan sesuai dengan yang diharapkan. Adapun hasil dari analisa tersebut adalah sebagai berikut:

\section{Deskripsi Sistem}

Sistem ini dirancang sebagai upaya mempermudah pemberian pakan kepada kucing yang dilengkapi dengan Modul RTC DS3231 yang berfungsi sebagai penyimpan waktu yang dapat membuka pintu wadah tendon ketika sudah menunjukan waktu yang sudah di tentukan. Motor servo berfungsi sebagai pembuka pintu wadah tendon dan menumpahkan wadah timbangan, motor servo yang digunakan adalah mini servo SG90 yang memiliki masukan tegangan $5 \mathrm{~V}$ dan memiliki putaran continous $180^{\circ}$. Load cell sebagai penimbang berat pakan kucing dengan berat 50gr.

\section{Perancangan Sistem}

Pada tahap perancangan pakan kucing, perancangan hanya dilakukan pada perangkat kerasnya saja karena tidak ada perancangan perangkat lunak yang di butuhkan. Pada sistem ini hanya pembuatan kode program yang dilakukan dengan perangkat lunak yang akan dijelaskan pada implementasi prangkat lunak. Berikut penjelasan dari perancangan perangkat keras.

\section{Perancangan Perangkat Keras}

Melakukan perancangan perangkat keras pada pemberi pakan kucing yang meliputi RTC sebagai penyimpan waktu, motor servo sebagai penggerak pintu dan wadah timbangan, load cell sebagai penimbang dan mikrokontroler arduino uno dan kebutuhan sistem yang lainnya, yang akan dijelaskan sebagai berikut

\section{Perancangan Modul RTC}

Real Time Clock (RTC) berfungsi sebagai penghitung waktu secara real time. RTC dapat menghitung waktu secara akurat dalam waktu yang cukup akurat sehingga dapat digunakan untuk menghitung jam pada sistem kandang. RTC membutuhkan daya $5 \mathrm{~V}$ (VCC) yang disuplai dari Arduino Uno dan Ground (GND). Selain itu RTC mempunyai pin SDA dan SCL yang harus dihubungkan dengan pin SDA dan SCL pada Arduino Uni pada pin A4 dan A5 sebagai pin alternatif.

Tabel 1. Tabel konfigurasi RTC dengan Arduino Uno.

\begin{tabular}{cl}
\hline Arduino Uno & RTC \\
\hline 5V & VCC \\
GND & GND \\
SDA/A4 & SDA \\
SCL/A5 & SCL \\
\hline
\end{tabular}

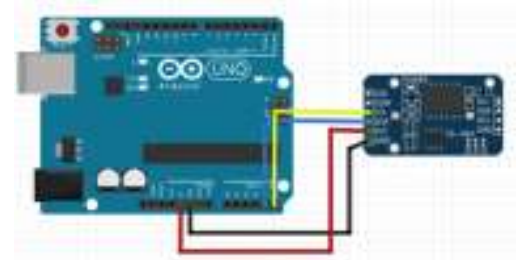


- Gambar 7. Rangkaian RTC pada Arduino Uno

Gambar 7 menjelaskan rangkaian RTC dengan konfiurasi pin SDA dan SDL yang terhubung pada Pin Arduino A4 dan A5 sedangkan Pin VCC dan GND terhubung pada Pin arduino 5V dan GND.

\section{Perancangan Motor Servo}

Mini servo adalah alat yang digunakan untuk membuka wadah pakan tandon sehingga pakan bisa jatuh ke wadah timbangan. Mini servo dipasang ke wadah timbangan untuk menggerakkan wadah agar menjatuhkan pakan ke saluran wadah pakan. Servo yang digunakan ada 2 yaitu 1 servo untuk membuka pintu wadah tandon dan 1 servo untuk mengerakkan wadah timbangan

- Tabel 2. Konfigurasi wadah pakan tandon (mini servo) dengan Arduino Uno.

\begin{tabular}{cc}
\hline Pin Motor servo & Pin Arduino Uo \\
\hline VCC & $5 \mathrm{~V}$ \\
GND & GND \\
IN & Pin A,5 \\
\hline
\end{tabular}

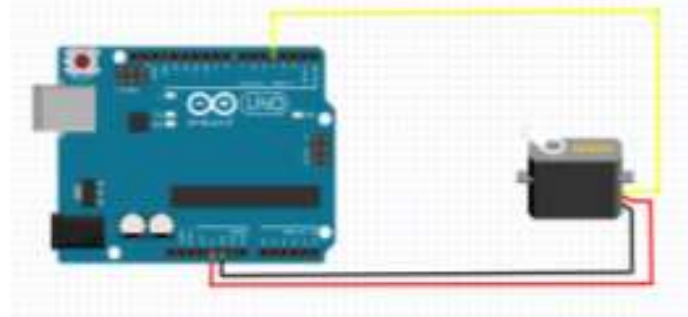

- Gambar 8. Rangkaian servo pada Arduino Uno

Gambar 8 menjelaskan rangkaian servo pada arduino uno dimana motor servo 1 dihubungkan ke pin A4 dan servo 2 dihubungkan ke pin A5

\section{Perancangan Sensor Berat (Load Cell)}

Load cell adalah sensor yang berfungsi menghitung berat beban. Load cell dipasang dengan wadah penampung bertujuan untuk menimbang berat pakan yang dikeluarkan sehingga dapat diteruskan kesaluran pengeluaran

\begin{tabular}{ccc} 
& Tabel 3. Konfigurasi Pin Load Cell dengan Arduino Uno. \\
\hline Load Cell & Modul H X 711 & Pin Arduino Uno \\
\hline E+ & VCC & 5V \\
E & GND & GND \\
A & SCK & PIN 3 \\
A+ & DT & PIN 2 \\
\hline
\end{tabular}

Konfigurasi ini mengharuskan Load cell modul HX711 ke arduino dengan mengkalibrasi berat 50 gr. Konfigurasi ini bertujuan mengatur berat pakan yang bertujuan menutup pintu wadah pakan utama dan memutar wadah penampung. 


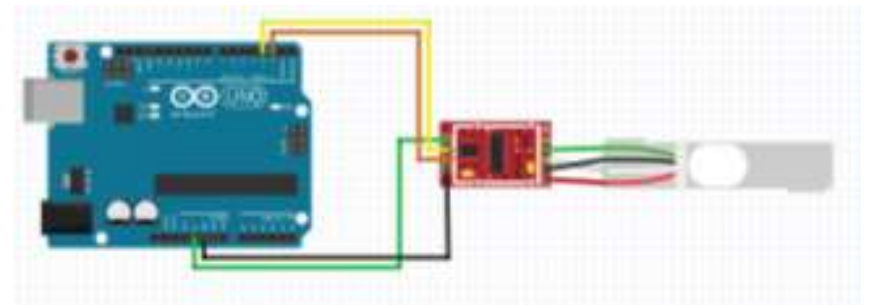

- Gambar 9. Rangkaian Load Cell modul HX711 dan Arduino Uno

Gambar 9 menjelaskan rangkaian Load cell pada Arduino dimana Pin SCK terhubung pada A3 dan pin DT terhubung pada A2.

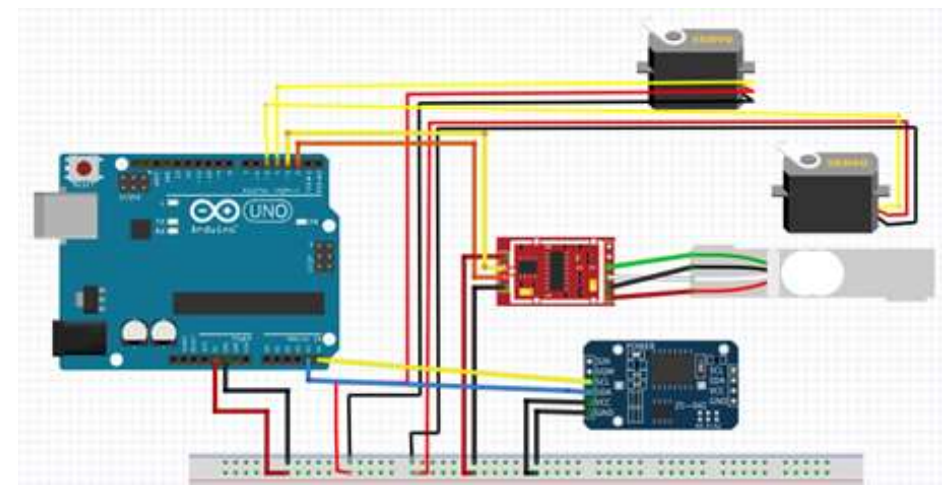

- Gambar 10. Rangkaian keseluruhan sistem

Gambar 10 menjelaskan rangkaian keseluruhan alat pemberi pakan kucing yang dikontrol oleh arduino uno dengan konfigurasi RTC pada pin SDA dan SCL yang berfungsi sebagai penyimpan waktu. Servo 1 pada pin A4 yang berfungsi untuk membuka pintu wadah tandon dan servo 2 pada A5 yang berfungsi untuk menumpahkan wadah timbangan. Load cell pada pin 2 dan pin 3 dengan fungsi untuk menimbang berat pakan. Semua pin GND pada setiap perangkat dihubungkan ke GND pada arduino uno.

\section{Implementasi Sistem}

Setelah perancangan selesai maka di lanjutkan pada tahapan implementasi sistem. Pada tahap ini terdapat 2 implemenasi yaitu implementasi prangkat keras dan implementasi perangkat lunak.

\section{Implementasi Perangkat Keras}

Tahapan implementasi pada perangkat keras dilakukan dengan pembuatan rangkaian sistem alat pemberi pakan kucing, pada pengimplementasian perangkat keras sistem terdapat 2 bagian yaitu, bagian pertama pengimplementasian rangkaian sistem dibagian dalam box pakan dan bagian kedua pengimplementasian rangkaian sistem dibagian dalam box control. 


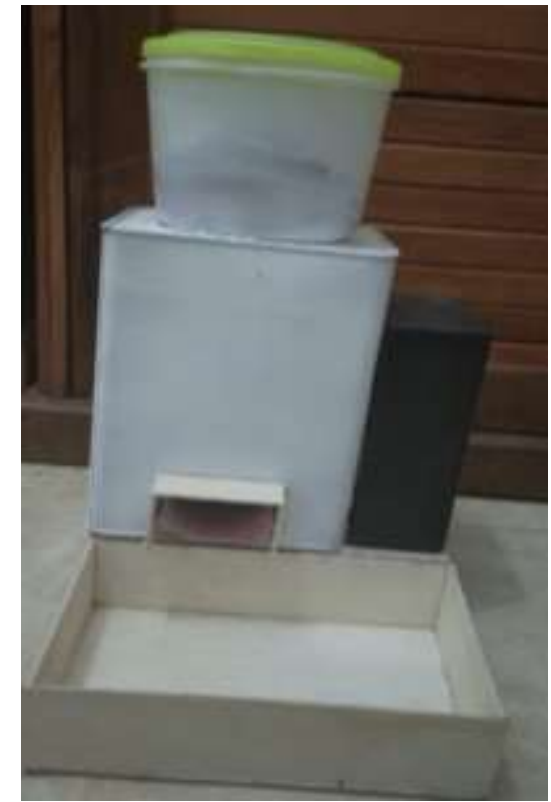

- Gambar 11. Bentuk keseluruhan sistem dishwasher dengan pengering

Gambar 11 menjelaskan desain perangkat alat dimana pakan akan ditaruh pada tandon penyimpanan pakan kemudian jika waktu sudah menunjuk pada jam pemberian pakan maka servo akan membuka pintu wadah tandon agar pakan jatuh pada wadah timbangan. Setelah itu load cell akan menimbang berat pakan, ketika pakan sudah mencapai berat $50 \mathrm{gr}$ maka akan memberi perintah kepada servo atas untuk menutup pintu tandon dan akan memberi perintah pada servo bawah untuk menumpahkan wadah timbangan ke saluran wadah pakan kucing.

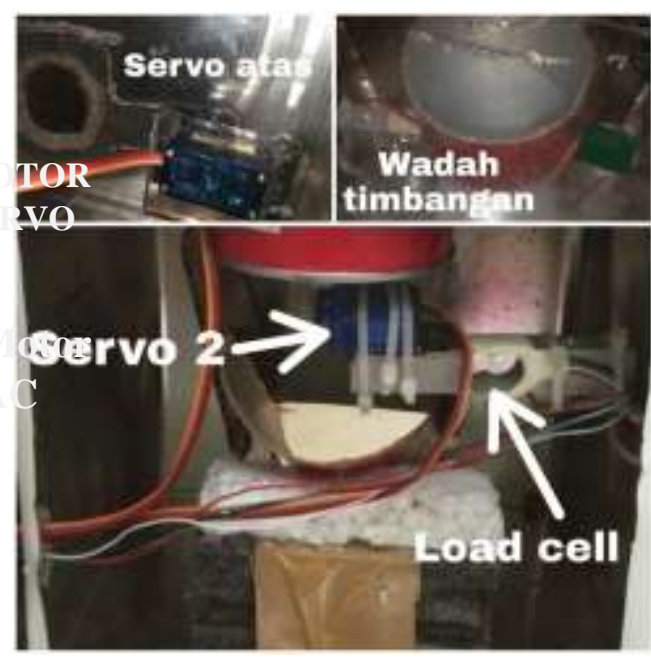

- Gambar 12. Implementasi sistem pada bagian dalam kotak

Pada gambar 12 merupakan rangkaian sistem ruang bagian dalam beberapa komponen yang sudah ditandai merupakan komponen yang bertugas mengeluarkan pakan. Servo atas berfungsi sebaga penggerak atau pembuka pintu wadah tandon sehingga pakan dapat keluar dan jatuh ke wadah timbangan untuk ditimbang. Load cell berfungsi sebagai timbangan untuk menghitung berat pakan yang dijatuhkan bilamana pakan mencapai berat yang sudah ditentukan maka akan mengirim sinyal ke servo atas untuk menutup wadah pakan utama dan kemudian dilanjutkan servo kedua untuk menggerakan wadah timbangan untuk menumpahkan pakan ke saluran wadah pakan kucing. 


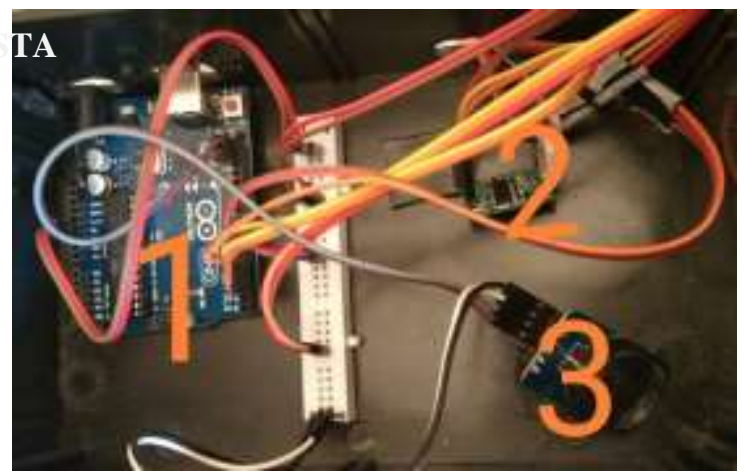

Gambar 13. Merupakan Implementasi sistem pada Box Kontrol

Pada gambar 13 adalah rangkaian sistem pemberi pakan kucing di box kontrol. Merupakan komponen yang berperan untuk mengontrol komponen dalam box sehingga dapat berfungsi dengan benar sesuai yang diharapkan. Pada gambar 4.7 yang ditunjukan nomer 1 merupakan Arduino Uno berfungsi sebagai tempat pemproses kode program yang telah dibuat. Dengan adanya Arduino Uno dapat membuat alat otomatisasi yang bekerja sesuai dengan program yang telah dibuat. Komponen selanjutnya yang ke 2 adalah modul load cell HX711 berfungsi sebagai pengukuran berat yang diinginkan. Komponen ke 3 merupakan RTC yang berfungsi untuk menghitung ataupun menyimpan waktu dengan Presisi.

\section{Implementasi Peangkat Lunak}

Tahap Implemetasi pada perangkat lunak ini dilakukan pembuatan kode program sistem, yang di implementasikan dengan software Arduino IDE 1.8.5 yang di install pada laptop.

Tabel 4. Kode program perangkat lunak pada Arduino IDE

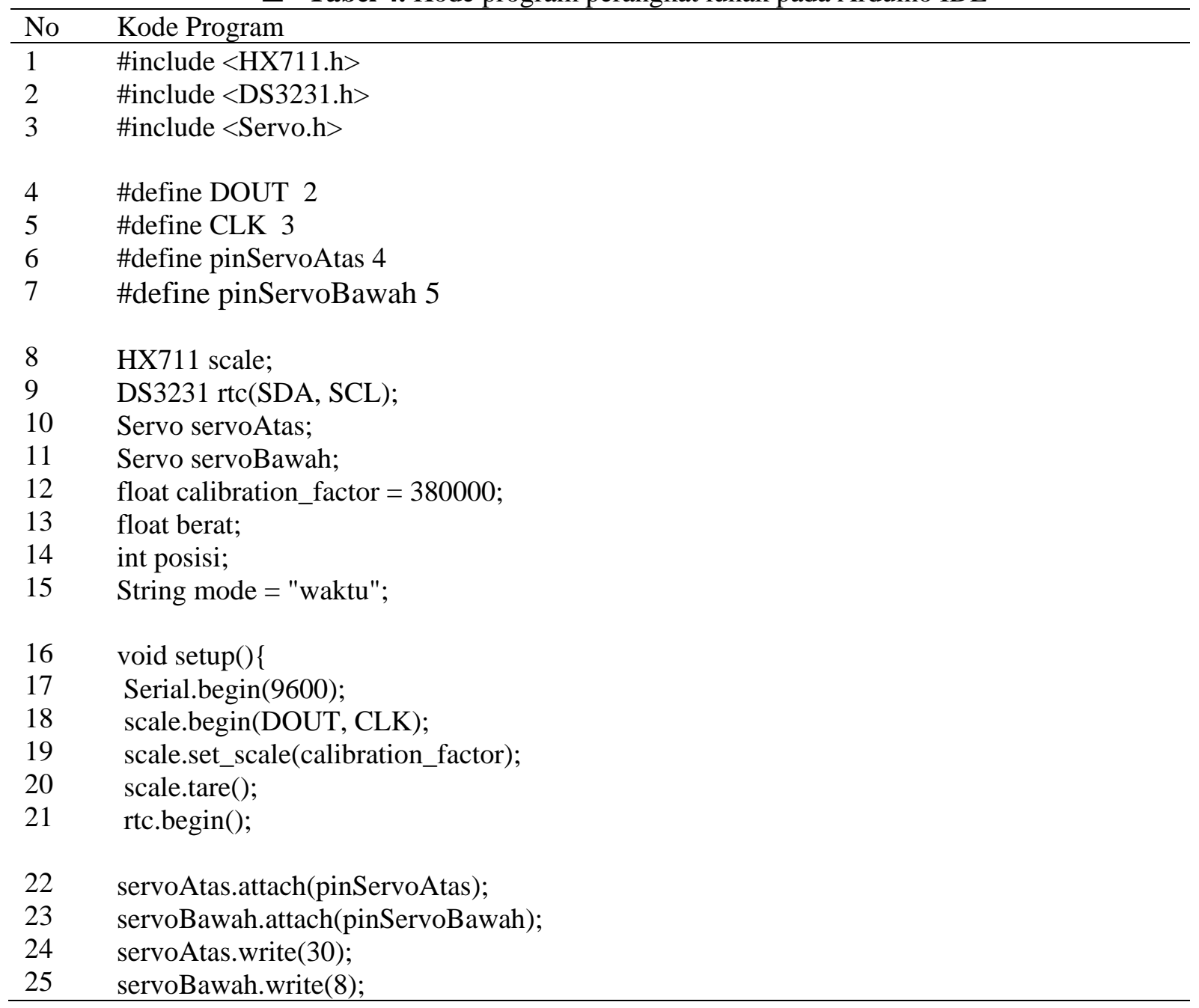




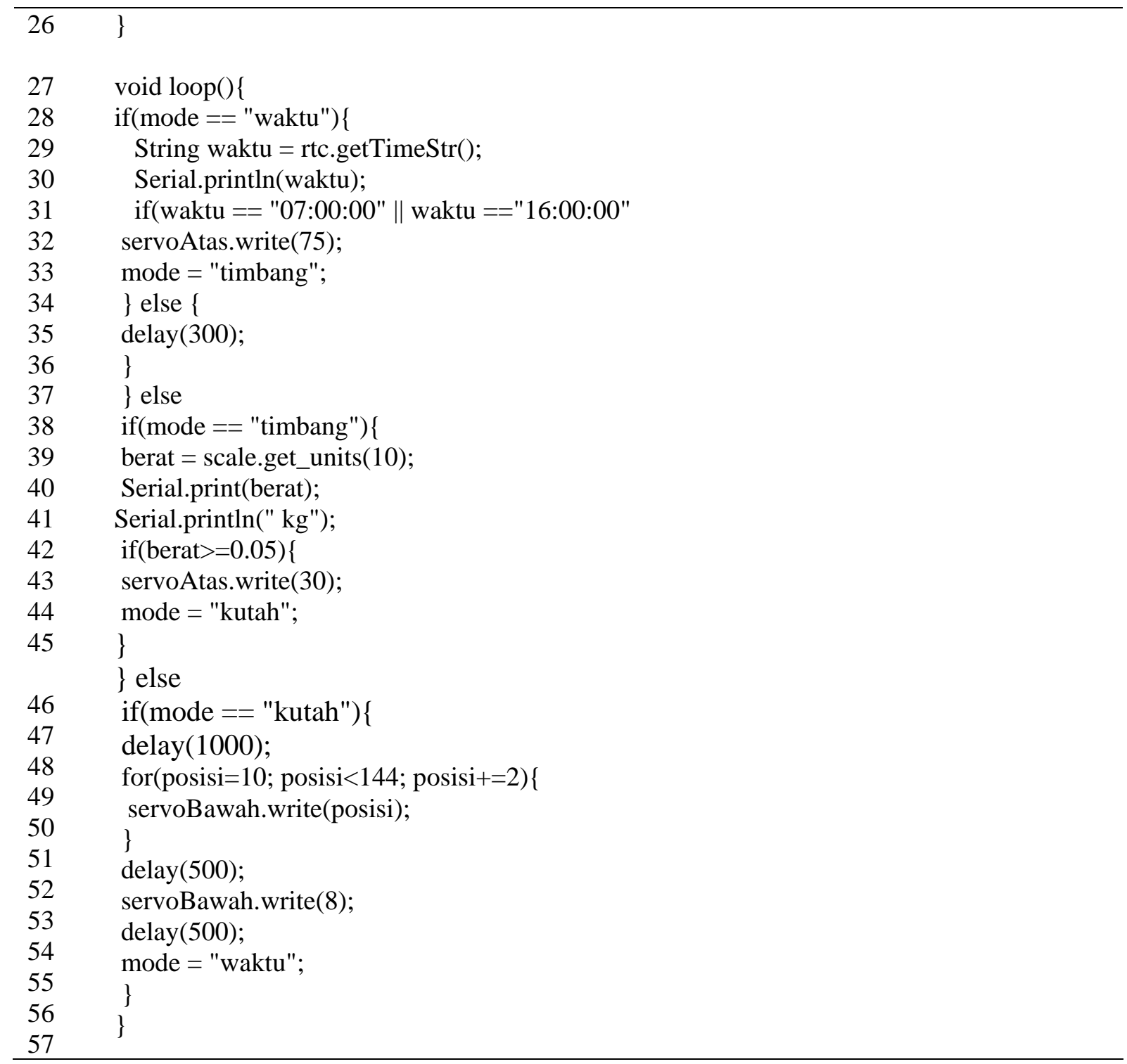

Pengujian terhadap alat pemberi pakan kucing tipe kering ini dilakukan dengan cara menguji bebrapa alat. Pertama, RTC sebagai penyimpan waktu, ketika sudah mencapai waktu yang ditentukan maka akan mengirim perintah ke Arduino uno. Kedua, motor servo disini menggunakan mini servo SG90 yang digunakan untuk membuka pintu wadah tendon, ketika sudah mencapai waktu pemberian pakan maka servo akan bergerak. Ketiga, load cell sebagai penimbang berat pakan yang dikeluarkan, ketika pakan diwadah timbangan sudah mencapai berat 50gr maka akan memberi perintah ke Arduino untuk menutup pintu wadah tendon. Ke empat mini servo SG90 bawah yang ditempatkan di bawah wadah timbangan akan menumpahkan wadah timbangan ke saluran wadah pakan ketika pintu wadah tendon tertutup.

Proses pembukaan pintu wadah tendon ketika mencapai waktu pukul 07:00 dan 16:00 ditunjukkan pada tabel 5

Tabel 5. Proser berjalannya RTC dan servo

\begin{tabular}{ccccc}
\hline \multirow{2}{*}{ NO } & WAKTU ALAT & MOTOR SERVO & \multicolumn{2}{c}{ BUKA WADAH TANDON } \\
\cline { 3 - 5 } 1 & $07: 00: 00$ & Bergerak & BISA & TIDAK BISA \\
\hline
\end{tabular}


$\mathrm{V}$ table 6

Proses Menimbang berat pakan tipe kering yang dikeluarkan dengan berat 50gr ditunjukkan pada

Tabel 6. Proser berjalannya Timbangan dan servo

\begin{tabular}{|c|c|c|c|c|c|}
\hline \multirow{2}{*}{ NO } & \multirow{2}{*}{ TIMBANGAN } & \multicolumn{2}{|c|}{ TUTUP WADAH TANDON } & \multicolumn{2}{|c|}{ TUMPAH } \\
\hline & & BISA & TIDAK & BISA & TIDAK \\
\hline 1 & $0.01 \mathrm{Kg}$ & - & $\mathrm{V}$ & - & $\mathrm{V}$ \\
\hline 2 & $0.02 \mathrm{Kg}$ & - & $\mathrm{V}$ & - & $\mathrm{V}$ \\
\hline 3 & $0.03 \mathrm{Kg}$ & - & $\mathrm{V}$ & - & $\mathrm{V}$ \\
\hline 4 & $0.04 \mathrm{Kg}$ & - & $\mathrm{V}$ & - & $\mathrm{V}$ \\
\hline 5 & $0.05 \mathrm{Kg}$ & $\mathrm{V}$ & - & V & - \\
\hline
\end{tabular}

Hasil Pengujian :

1. Servo berfungsi dengan baik membuka dan menutup pintu wadah tandon dengan waktu pukul 07:00 dan pukul 16:00.

2. Sensor load cell berfungsi dengan baik menimbang berat pakan kering $50 \mathrm{gr}$.

3. Servo bawah/kedua berfungsi dengan baik menggerakkan wadah timbangan untuk menumpahkan pakan kesaluran wadah pakan.

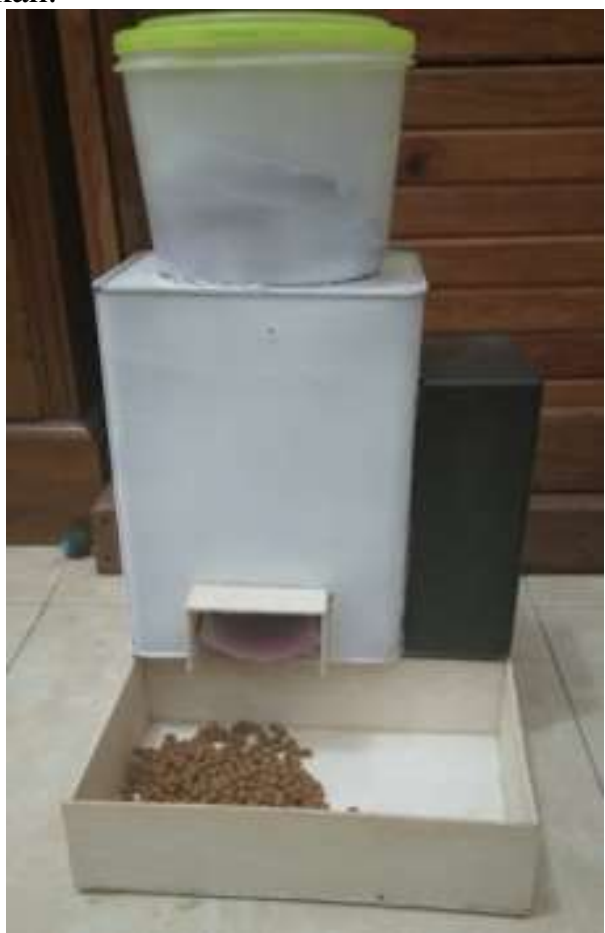

Gambar 14. Sistem pemberi pakan kucing yang sudah beroperasi

Berikut merupakan rangkuman hasil dari pengujian alat pemberi pakan kucing otomatis

\section{Pakan keluar}

\section{Sensor}




\begin{tabular}{|c|c|c|c|c|c|c|c|}
\hline \multirow[t]{2}{*}{ Percobaan } & \multirow[b]{2}{*}{ 07:00 } & \multirow[b]{2}{*}{ 16:00 } & \multirow[t]{2}{*}{ Timbangan } & \multicolumn{2}{|c|}{ keluarkan } & \multirow[b]{2}{*}{ 07:00 } & \multirow[b]{2}{*}{ 16:00 } \\
\hline & & & & 07:00 & 16:00 & & \\
\hline 1 & $\mathrm{~V}$ & $\mathrm{~V}$ & Berfungsi & $53 \mathrm{gr}$ & $52 \mathrm{gr}$ & $2 \mathrm{gr}$ & - \\
\hline 2 & V & V & Berfungsi & $50 \mathrm{gr}$ & $50 \mathrm{gr}$ & - & - \\
\hline 3 & V & V & Berfungsi & $52 \mathrm{gr}$ & $50 \mathrm{gr}$ & - & $3 g r$ \\
\hline 4 & V & V & Berfungsi & $50 \mathrm{gr}$ & $50 \mathrm{gr}$ & - & - \\
\hline 5 & V & V & Berfungsi & $50 \mathrm{gr}$ & $50 \mathrm{gr}$ & - & - \\
\hline 6 & V & V & Berfungsi & $50 \mathrm{gr}$ & $50 \mathrm{gr}$ & - & $2 \mathrm{gr}$ \\
\hline 7 & V & V & Berfungsi & $50 \mathrm{gr}$ & $50 \mathrm{gr}$ & - & - \\
\hline
\end{tabular}

Tabel 7. Pengujian Keseluruhan Alat Pemberi Pakan Kucing

Berdasarkan pengujian yang telah dilakukan menunjukan bahwa sistem berjalan dengan benar. Arduino mampu memberikan perintah yang benar kepada Motor Servo, Load Cell dan RTC sesuai dengan coding yang telah diperintahkan. Percobaan pertama berhasil mengeluarkan pakan dengan berat $53 \mathrm{gr}$ pada jam pertama dan 52gr pada jam ke dua dengan kondisi isi wadah tandon penuh dan sisah pakan yang dimakan 2gr. Pada percobaan ke dua berhasil mengeluarkan pakan dengan berat 50gr pada jam pertama dan jam ke dua dengan kondisi isi wadah tandon $3 / 4$ dan sisah pakan yang dimakan habis.

Dari tujuh percobaan di atas dapat diperkirakan pakan yang keluar melebihi dari berat yang ditentukan jika isi pakan di wadah utama lebih dari $3 / 4$ atau penuh. Namun jika isi pakan di wadah utama $3 / 4$ ke bawah maka pakan yang keluar lebih presisi

\section{KESIMPULAN}

Alat pemberi pakan kucing berbasis Arduino uno dengan memanfaatkan RTC sebagai penentu jadwal untuk menggerakkan servo untuk membuka wadah pakan utama. Kemampuan sensor load cell yang dapat menimbang berat pakan yang dikeluarkan. Setelah berat pakan sudah sesuai maka servo menjatuhkan wadah timbangan ke wadah pakan. Presentase uii coba yang dilakukan mencapai 99\%. Dimana jika wadah utama diisi penuh pakan yang di keluarkan lebih banyak. Namun jika pakan terisi $3 / 4$ maka pakan yang keluar akan lebih presisi.

\section{SARAN}

Alat pemberi pakan kucing otomatis ini diharapkan dapat di kembangkan kearah yang mempunyai sistem fungsional yang lebih kompleks lagi. Beberapa saran antara lain menambahkan penanda jika wadah pakan habis.

\section{DAFTAR PUSTAKA}

[1] Agil Shoendian, S. 2018. Rancang Bangun Alat Pemberi pakan-minuum Burung Cinta( Love bird ) Berbasis Mikrokontroler AtMega16. Jurnal Teknik Elektro. Fakultas Teknik Universitas 17 Agustus 1945 Surabaya.

[2] Budiharto, Widodo. 2005. Perancangan Sistem dan Aplikasi Mikrokontroller. Penerbit PT. Elex Media Komputindo: Jakarta.

[3] Fadhilah, Debby. "Kapan dan Berapa Banyak Kucing Harus Makan”. 2016. https://ilmuveteriner.com/kapan-dan-berapa-banyak-kucing-harus-makan/.

[4] Harel, D.A. 2018. Pengembangan Prototipe Sistem Otomasi Alat Pemberi Makan Ikan Terjadwal Pada Aquarium Berbasis Arduino UNO R3. Jurnal Widyakala Volume 5 No. 2 September 2018. Program Studi Informatika Universitas Pembangunan Jaya. 
[5] Kadir, Abdul. 2013. Panduan Praktis Belajar Mikrokontroller Arduino. Penerbit Andi Offset : Yogyakarta.

[6] Saputra, D.D. 2019. Sistem Kontrol Kualitas Pakan Ayam Berbasis Arduino MEGA. Jurnal Teknik Informatika dan Sistem Informasi. Volume 4 Nomor 2 Agustus 2018. Jurusan Teknik Elektro Universitas Muhammadiyah Sidoarjo.

[7] Suprianto. 2014. Rancang Bangun Alat Pemberian Pakan Ikan Koki Otomatis Pada Aquarium Berbasis Mikrokontroler AT89S52. Jurnal Teknik Informatika, Fakultas Teknik Universitas Kanjuruan Malang.

[8] Suwed, M. A., \& Napitupulu, R. M. 2011. Panduan Lengkap Kucing. Jakarta: Penebar Swadaya.

[9] Yohanna Margaretha, Desy Tri Natasia Lumban Toruan. 2018. Rancang Bangun Sistem Pemberian Pakan dan Minum Ayam Secara Otomatis. Jurnal Teknik Informatika dan Sistem Informasi. Volume 4 Nomor 2 Agustus 2018. Jurusan Teknik Informatika Universitas Methodist Indonesia.

[10] Ervani, Rendra. "Modul RTC DS3231". 2019.https://arduino.rezaervani.com/2019/03/02/modulrtc-ds3231/.

[11] Dermanto, Trikueni. "Desain Sistem Kontrol”. 2014. http://trikuenidesainsistem.blogspot.com/2014/03/Pengertian-Motor-Servo.html 